\title{
A RARE CLINICAL PRESENTATION DUE TO SMALL CORTICAL INFARCTION: ISOLATED WRIST DROP
}

\author{
Hatice KÖSE ÖZLECE, Nergiz HÜSEYINOĞLU
}

\author{
Kafkas University Faculty of Medicine Department of Neurology, Kars, TURKEY
}

\begin{abstract}
Isolated wrist drop due to stroke is infrequently observed, and often misdiagnosed as peripheral neuropathy. It is important to make the differential diagnosis correctly because drop hand that results from peripheral pathology requires a completely different treatment strategy than central pathology. In addition, small infarcts are important to identify in order to optimise secondary prophylaxis. In this report, we describe an 83-year-old man, with isolated drop hand due to acute small cortical infarction in the left precentral gyrus and present this situation in light of the literature.
\end{abstract}

Key Words: Isolated wrist drop, cortical infarction, precentral gyrus.

\section{KÜÇÜK KORTIKAL İNFARKTA BAĞLI NADİR GÖRÜLEN BİR KLİNIK TABLO: İZOLE DÜŞÜK EL}

\section{ÖZET}

Serebrovasküler olaylara bağlı gelișen izole düşük el tablosu oldukça nadir görülür ve genellikle periferik sinir lezyonları șeklinde yanlış tanı alır. Tedavi stratejileri tamamen farklı olan santral ve periferik patolojilere bağlı gelișen düşük el ayırıcı tanısı oldukça önmelidir. Ayrıca küçük kortikal infarktların tanınması, özellikle sekonder proflaksi açısından önemlidir. Bu vaka takdiminde, 83 yaşında erkek hasta küçük kortikal infarkt nedeni ile gelişen izole düşük el tanısı ile literature ışığında sunulmuștur.

Anahtar Sözcükler: İzole düşük el, kortikal infarkt, presentral girus.

\section{INTRODUCTION}

The wrist drop, also called drop hand or carpoptosis, usually occurs as result of focal compression or entrapment of the radial nerve. However, isolated drop hand may also develop, although rarely, from cerebrovascular events. Less than $1 \%$ of stroke patients have isolated hand palsy as a result of lesions of the cortical motor hand area [1]. Localization of the lesions, which can present as peripheral nerve lesions, is variable, including the precentral gyrus, angular gyrus, capsula and ventroposterior thalamus [2]. In some of these cases, ulnar, radial and median nerves influences are dominant, although some cases may develop weakness in the whole hand, often misdiagnosed as peripheral nerve pathologies $[3,4,5]$. It is important to make the differential diagnosis correctly because drop hand that results from peripheral pathology requires a completely different treatment strategy than drop hand that results from central pathology. In this report, we describe a patient with isolated drop hand due to a small cortical infarction, and present this situation in light of the literature.

\section{CASE}

An 83-year-old man, a chronic smoker, was admitted acutely with weakness of the extension of the right thumb, index finger and wrist. He had a history of hypertension, type 2 diabetes, hyperlipidemia, and ischemic heart disease for approximately fifteen years. He was treated with perindopril-indapamide, oral antidiabetics and atorvastatin. In addition, warfarin was started for atrial fibrilation, but the patient used this medication irregularly. He complained of weakness

\footnotetext{
Corresponding author: Asst. Prof. Hatice Köse, MD. Kafkas University Faculty of Medicine Department of Neurology, Kars, Turkey.

Phone: +904742251430 E-mail: haticekse@hotmail.com

Received: $31.03 .2014 \quad$ Accepted: 10.05 .2014

This article should be cited as following: Köse Özlece $\mathrm{H}$, Hüseyinoğlu N. A rare clinical presentation due to small cortical infarction: isolated wrist drop. Turkish Journal of Cerebrovascular Diseases 2015; 21 (1): 36-39. doi:10.5505/tbdhd.2015.05706.
} 
of the right fingers and wrist without sensory complaints, which occurred abruptly after awakening.

Result of general physical examinations were within normal ranges. Some blood tests including liver, renal and thyroid functions, vitamin B12, folic acid, prothrombin time and activated partial prothrombin time, and creatine kinase were within the normal ranges. Glucose, LDL, total cholesterol and HbA1c values were high. Atrial fibrillation, which is the major cause of cardioembolic stroke, was showed in electrocardiography. Transthorasic echocardiography showed impairment of left ventricular relaxation with no cardiac source of embolus. On neurological examination, his right hand and all of his fingers were flexed. Revealed weakness was grade 1 (on the Medical Research Council Scale) at the wrist and finger extensors (extensor digitorum communis, extensor indicis proprius, extensors carpi ulnaris and radialis). There was no hypoesthesia, hyperalgesia, allodynia or dysesthesia on the hand. No other neurological impairment was found. Initial differential diagnosis included radial neuropathy, brachial plexus pathologies, acute tendon rupture of forearm extensors, focal entrapment of the posterior interosseous nerve, multifocal motor neuropathy and stroke. Nerve conduction velocities and needle electromyography studies were within normal ranges, therefore ruling out of peripheral lesions of the radial nerve. Due to the many risk factors of stroke and the sudden nature of onset, a brain MRI was done. Diffusion weighted imaging (DWI) revealed an acute ischemic infarct in the left precentral gyrus (Figure 1). The MRA demonstrated atherosclerotic changes in the internal carotid artery bilaterally, without significant stenosis or source of embolus. The patient was diagnosed with cardioembolic stroke due to atrial fibrillation, and warfarin treatment was started. He made a total recovery and was discharged in good general condition without any neurological impairment.

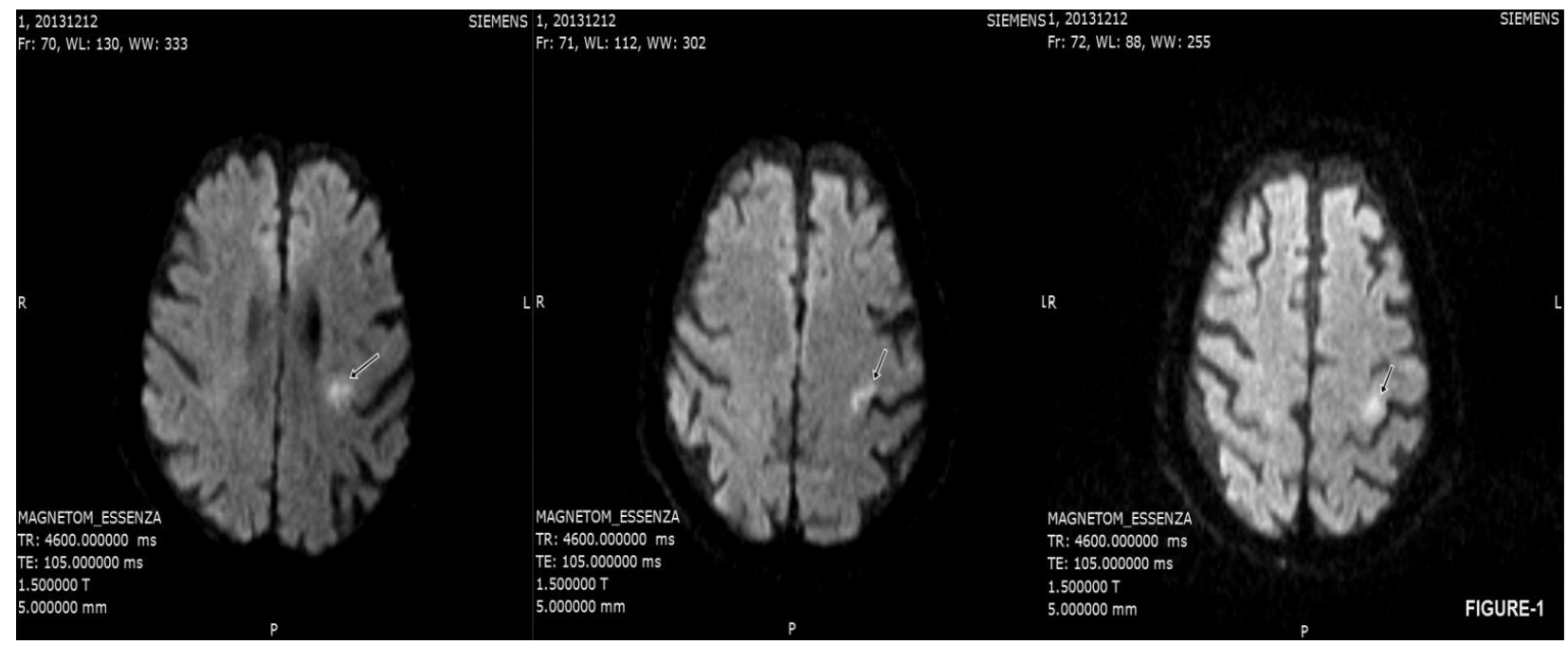

Figure 1. Diffusion weighted imaging (DWI) revealed an acute ischemic infarct in the left precentral gyrus.

\section{DISCUSSION}

Drop hand may develop from many types of lesions of peripheral or central origin. In this study we described a patient who had suffered weakness of the extension of the right thumb, index finger and wrist. First, we considered peripheral lesions of the radial nerve (Saturday night palsy) because of patients with cachexia, and those with a history of sleeping on the arm. However, there were no sensory deficits and the patient had severe risk factors for vascular disease such as older age, hypertension, hyperlipidemia and diabetes mellitus. ENMG was not helpful for diagnosis in the acute phase, despite normal readings. Thus, stroke was considered as a rare cause of drop hand and detected by DWI.

Isolated hand paresis has been reported as a result of embolic stroke involving the hand knob area, small bleeding or lacunar infarcts secondary 
to minor vascular diseases or large-artery atherosclerotic infarct of the vascular watershed area [6]. In addition, spontaneous carotid artery dissection has been reported as a rare cause of stroke [7]. Kim et al.[8] reported that patients had ulnar-like deficits associated with severe stenosis or occlusion of the carotid artery, whereas radiallike deficits are generally associated with an embolic mechanism. Our patient, who had radiallike deficits, was diagnosed with cardioembolic stroke due to atrial fibrillation. He also had many major vascular and stroke risk factors such as hypertension, type 2 diabetes, hyperlipidemia and ischemic heart disease.

Some previous studies have described patients who had predominant involvement of ulnar, median or radial side fingers. However, there are a limited number of studies reporting only radial-like lesions related to acute ischemic stroke. Dafotakis et al. [9] reported on a patient who had right dominant bilateral wrist drop due to ischemic lesions in both hand knobs in the precentral gyri. Further, two patients have been described with radial-like deficit secondary to a small cortical infarct, localized on the contralateral precentral gyrus [10]. In both cases, both the radiological and clinical findings were similar to our patient's features. However, there are cases reported in the literature that have similar clinical features but different localizations of the brain lesions. A case with right wrist drop has been reported with the lesion in the middle and posterior cerebral arteries watershed territory [11]. In another study, a patient was described with wrist drop following an anterior cerebral and middle cerebral artery border zone infarct due to spontaneous carotid artery dissection [7]. Emma et al. [3] reported a patient with weakness and numbness of the thumb and forefinger of the left hand who had a small acute infarct in the right corona radiata Therefore, the authors investigated the relationship between lesion location and the side of the hand weakness. A previous study suggested that the medial portion of the precentral knob topographically represents the ulnar-side fingers, while the border zone area between the middle cerebral artery and anterior cerebral artery represents the radial-side fingers [8]. In contrast to this study, Takahashi et al. [12] investigated five patients with ulnar and radial side involvement and reported that the lesions in the precentral gyrus were similar in all patients, independent of the involvement sides, and were localized to the posterior portion of the precentral gyrus. Seven patients have been reported with sensory motor deficit in a peripheral nerve pattern due to brain lesions. Five of these had an ulnar-like and two had median-like deficits. The infarcts were located in the thalamus and corona radiata [4]. A recent study described patients with isolated hand palsy and involvement of the inferior parietal lobule and postcentral gyrus [13]. In addition, isolated hand pareses without distinction of the specific nerve side involvement were examined for identification of the motor hand area in the brain. Çelebisoy et al. [14] reported that the hand area in the cerebral motor cortex is located in the middle to lower portion of the anterior wall of the central sulcus. Lesions of this region may result in isolated hand paresis. It has been observed that the motor hand area is located in the epsilon or inverted omega-shaped precentral knob, in axial MRI although [15]. Previous studies have reported that the control center of hand movement is not limited to the knob area of the precentral gyrus. Consistent with the previous studies, our case suggests that the precentral gyrus in the parietal lobe is related to control of the motor function of the hand. Our patient made a good recovery and was discharged without neurological impairment after ten days. In previous studies, patients with isolated hand weakness have been reported to recover without sequelae after medical treatment and physiotherapy $[4,13]$. The neural mechanism underlying recovery of function is still not completely understood, however it may be related to the adjacent cortical areas taking over the functions of the damaged area [16]. Further, Duffau et al. [17] reported the existence of multiple cortical representations of finger, wrist and forearm movements in the primary motor cortex and total recovery related to beneficial reorganization of the primary motor cortex after damage.

Finally, isolated drop hand mimicking a peripheral radial nerve lesion as a result of cerebrovascular disease is rare. In our case, the patient's advanced age and presence of severe risk factors led us to investigate central origin lesions, which were detected with MRI. We believe that it is important to differentiate stroke from peripheral lesions because of the requirement for different treatment modalities and secondary prophylaxis.

Turkish Journal of Cerebrovascular Diseases 2015; 21 (1): 36-39 


\section{REFERENCES}

1. Castaldo J, Rodgers J, Rae-Grant A, Barbour P. Diagnosis and management of acute stroke producing distal arm monoparesis. J Stroke Cerebrovasc Dis 2003;12:253-8.

2. Phan TG, Evans BA, Huston J. Pseudoulnar palsy from a small infarct of the precentral knob. Neurology. 2000 Jun 13;54(11):2185.

3. Rankin EM, Rayessa R, Keir SL. Pseudoperipheral palsy due to cortical infarction. Age Ageing. 2009 Sep;38(5):623-4. doi: 10.1093/ageing/afp025. Epub 2009 Mar 12.

4. Lampl Y, Gilad R, Eshel Y, Sarova-Pinhas I. Strokes mimicking peripheral nerve lesions. Clin Neurol Neurosurg. 1995 Aug; 97(3):203-7.

5. Chen PL, Hsu HY, Wang PY. Isolated hand weakness in cortical infarctions. J Formos Med Assoc. 2006 Oct;105(10):861-5.

6. Pikula A, Stefanidou M, Romero JR, Kase CS. Pure motor upper limb weakness and infarction in the precentral gyrus: mechanisms of stroke. J Vasc Interv Neurol. 2011 Jan;4(1):10-3. 7. Pikula A, Romero JR, Kase CS. An unusual clinical presentation of ischemic stroke due to carotid dissection: The wrist drop. Int J Neurolo.2009; 11(2).

8. Kim JS. Predominant involvement of a particular group of fingers due to small, cortical infarction. Neurology. 2001 Jun 26;56(12):1677-82.

9. Dafotakis M, Schiefer J, Wiesmann M, Mühlenbruch G. [Bilateral wrist drop - central or peripheral lesion?]. Fortschr Neurol Psychiatr. 2011 May;79(5):304-6. doi: 10.1055/s-00311273331. Epub 2011 May 3.
10. Uribe Roca C, Gatto EM, Micheli F. Neurology. Isolated weakness of index finger due to small cortical infarction. 2002 Dec 24;59(12):2010-1.

11. Hassan KM. Fractional arm weakness as presentation of stroke due to posterior borderzone infarct: A report of two cases. Ann Indian Acad Neurol. 2010 Oct;13(4):302-4.

12. Takahashi N, Kawamura M, Araki S. Isolated hand palsy due to cortical infarction: localization of the motor hand area. Neurology. 2002 May 14;58(9):1412-4.

13. Chen PL, Hsu HY, Wang PY. Isolated hand weakness in cortical infarctions. J Formos Med Assoc. 2006 Oct;105(10):861-5.

14. Celebisoy M, Ozdemirkiran T, Tokucoglu F, Kaplangi DN, Arici S. Isolated hand palsy due to cortical infarction: localization of the motor hand area. Neurologist. 2007 Nov;13(6):376-9.

15. Yousry TA, Schmid UD, Alkadhi H, et al. Localization of the motor and hand area to a knob on the precentral gyrus. Brain 1997; 120: 141-157.

16. Nardone R, Höller Y, Brigo F, Seidl M, Christova M, Bergmann J, Golaszewski S, Trinka E. Functional brain reorganization after spinal cord injury: systematic review of animal and human studies. Brain Res. 2013 Apr 4;1504:58-73. doi: 10.1016/j.brainres.2012.12.034. Epub 2013 Feb 8.

17. Duffau $\mathrm{H}$. Acute functional reorganisation of the human motor cortex during resection of central lesions: a study using intraoperative brain mapping. J Neurol Neurosurg Psychiatry. 2001 Apr;70(4):506-13. 